\title{
THE ROLES OF INTEGRATING INFORMATION COMMUNICATION TECHNOLOGY (ICT) IN TEACHING SPEAKING AT THE FIRST SEMESTER OF ENGLISH STUDENTS OF FKIP UIR
}

\author{
Betty Sailun $^{1)}$, Andi Idayani ${ }^{2)}$ \\ ${ }^{* 1}{ }^{* 2)}$ Universitas Islam Riau \\ email: bettysailun@edu.uir.ac.id \\ email: andiidayani@edu.uir.ac.id
}

\begin{abstract}
Speaking skill is an important part of the curriculum in language teaching, this makes it an important for students to be able to speak English. However, the goal of teaching speaking should improve students' communicative skills as a way to help students express themselves and learn how to follow the social and cultural rules appropriate in each communication circumstance. Hence, Information Communication Technology (ICT) can be used by the English teacher to enhance students' English Proficiency, especially speaking skill. Thus, the present study aims at investigating the role of Information Communication Technology (ICT) in speaking class at the first semester of English Students of FKIP UIR which consists of 42 students as sample of this research. The researchers used descriptive method and worked by using questionnaires as an instrument for collecting data. The researchers have found that the use of Information Communication Technology (ICT) increases students' motivation and their speaking performances. It also has great impact on students learning's effectiveness. In general, students prefered group work activities, free discussion, role play, or students' presentation. A large number of students declared that their lecturer used technology while teaching speaking. They claimed that using ICT has beneficial and helpful to speak the language. Finally, most students affirmed that the use of ICT developed their speaking skill, increased their knowledge, and creativity. Concerning their attitudes towards their preferable kind of technology that can be used in teaching, some prefer to use laptop/notebook and projector while others enjoyed watching videos.
\end{abstract}

Keywords: Teaching Speaking, Information Communication Technology (ICT)

\section{PERAN KOMUNIKASI INFORMASI TEKNOLOGI DALAM PEMBELAJARAN BERBICARA PADA SEMESTER PERTAMA SISWA BAHASA INGGRIS FKIP UIR}

\begin{abstract}
Abstrak
Keterampilan berbicara adalah bagian penting dari kurikulum dalam pengajaran bahasa. Namun, tujuan pengajaran berbicara diharapkan dapat meningkatkan kemampuan komunikatif siswa dalam mengekspresikan diri dan belajar bagaimana mengikuti peraturan sosial dan budaya yang sesuai dalam
\end{abstract}


setiap situasi komunikasi. Oleh karena itu, Teknologi Informasi Komunikasi dapat digunakan oleh guru bahasa Inggris untuk meningkatkan kemampuan bahasa Inggris siswa, terutama keterampilan berbicara. Dengan demikian, penelitian ini bertujuan untuk menyelidiki peran Teknologi Informasi Komunikasi di kelas berbicara pada semester pertama Mahasiswa Bahasa Inggris FKIP UIR yang terdiri dari 42 siswa sebagai sampel. Peneliti menggunakan metode deskriptif dan kuesioner sebagai data penelitian. Setelah mengumpulkan data dari kuesioner, peneliti telah menemukan bahwa penggunaan Teknologi Komunikasi Informasi dapat meningkatkan motivasi dan kinerja berbicara siswa. Ini juga berdampak besar pada keefektifan pembelajaran siswa. Secara umum siswa lebih memilih kegiatan kerja kelompok, diskusi bebas, permainan peran, atau presentasi. Sebagian siswa menyatakan bahwa dosen menggunakan teknologi saat mengajar keterampilan berbicara. Kemudian, siswa juga menyimpulkan bahwa penggunaan teknologi dapat mengembangkan kemampuan berbicara dan meningkatkan pengetahuan serta kreativitas mereka. Mengenai sikap mereka terhadap jenis teknologi yang lebih baik yang dapat digunakan dalam pengajaran yakni menggunakan laptop/notebook dan proyektor sementara yang lain memilih menonton video.

Kata kunci: Pengajaran Berbicara, Teknologi Informasi Komunikasi.

\section{INTRODUCTION}

Nowadays technology has brought a lot of changes to our life, especially in education and communication. In communication, the major changes happen in the way we communicate with other people. We do not need to meet them in person or face to face to say what is in our mind. We can simply phone them or do video chat using internet connection. In the past, we spent a long time to travel to a distant place, but now we just need hours or even minutes to go there using the latest technology in a form of transportation means.

The current era of technological revolution and the explosion of knowledge have witnessed a tremendous progress in the field of information technology. Indeed, modern technology has transformed the world into a small global village.
This development is reflected in many fields, but the field that benefits a lot is education. Therefore, Information Communication Techniques are increasingly integrating into our daily lives. They are changing the way we live, the way we spend our spare time and the way we work. They are known by other terms such as teaching and instructional aids. These include the use of slide projector, television, radio, and videos etc. Hence, the present research study will shed light on this new concept in education and investigate the use and effect of Information Communication Technology (ICT) in teaching English as a foreign language (EFL) in general and in teaching speaking more particularly.

Additionally, students have the opportunity to develop their spoken language competence. They used of the great advantages of technologies, 
which provide safe, motivating, and interactive environments. There was a great variety of resources, spontaneous feedback, exposure to real interaction, addresses to different needs, through which students accessed using Web-based environments to practice listening and speaking skills. Not only instructors are able to apply new methods of increasing their efficiency by achieving success, but they also update their tools and teaching strategies, so that students can be motivated, and their language skills can be improved as well.

In conclusion, the changes of technology have brought advantages to students and teachers. For instance, students can do their homework or assignment faster because of the use of internet. Teachers also get some advantages from it: They can combine their teaching skill with technology and produce some interesting materials to teach like colorful slides to deliver the lesson and animation to show how things happen. Consequently, technology itself has given us advantages to improve our life's quality. This research was limited to one area; that the use of ICTs was related to education and more precisely to the improvement of students' speaking skill.

\subsection{Teaching Speaking Skill}

Harmer (2088) suggests three main reasons to make the students apply or speak in the classroom. Firstly, speaking activities offer rehearsal chance, possibilities to practice real-life speaking within his safety classroom. Secondly, speaking tasks that students attempt to use any or all of the languages they

J-SHMIC, Vol 4, No 2, August 2017 understand give feedback for each of them teachers and students.

As a result, students gradually become autonomous language users. This suggests that they can be ready to use words and phrases fluently without terribly a lot of conscious thought. Smart speaking activities ought to be extremely participating for the students. If they are all collaborating totally and if the teacher has set up the activities properly, it will then provide sympathetic and useful feedback and they can get tremendous satisfaction from it. Thus, speaking activities are designed to promote speaking instead of having students speak only to practice specific construction.

Furthermore, among the four language skills, speaking has long been cited as the most significant ability EFL learners are supposed to master. In support of this, Ur (1996) put forward that speaking is the productive skill that comprises a notable role in learning the language; especially, because it, on the one hand, identifies the learners ${ }^{\text {ee }}$ mistakes while using the language, and, on the other hand, includes all the other skills of knowing that language.

In short, speaking, one of the language skills is responsible for the speech production. In this sense, it has been over emphasized as a central ability that promotes the overall success of communication among interlocutors.

\subsection{The Use of Information Communication Technology (ICT)}

In general, ICT is an umbrella term that includes any communication device or application, encompassing 
radio, television, cellular phones, computer and network hardware and software, satellite systems and so on, as well as the various services and applications associated with them, such as videoconferencing and distance learning. Additionally, according to Tinio (2002) ICTs are a "diverse set of technological tools and resources used to communicate, and to create, disseminate, store, and manage information." These technologies include computers, the Internet, broadcasting technologies (radio and television), and telephony.

As the popularity of English is expanding day by day and worldwide, the teachers of English feel the need of change in their language teaching methods. The use of Information and Communication Technology in language teaching has created a favorable context for reforming and exploring English language teaching models in the new age.

Peck and Domcott (1994)
outlined some reasons that
technologies should be used in
schools;

a. technology enables teachers to individualize instruction, which allows students to learn and develop at their own pace in a nonthreatening environment;

b. students need to be proficient at accessing, evaluating and communicating, and information;

c. technology can increase the quantity and quality of students' thinking and writing through the use of word processors;

d. technology can develop students' critical thinking and allowing them to organize, analyze, interpret, develop, and evaluate their own work; e. technology can encourage students' artistic expression; technology enables students to access resources outside the school;

f. technology can bring new and exciting learning experiences to students; students need to feel comfortable using computer, since they will become an increasingly important part of students' world;

g. technology creates opportunities for students to do meaningful work, and; schools need to increase their productivity and efficiency.

Al-Zaidiyeen (2010) identified three objectives for the use of ICT in education. First, the use of ICT as object of study, then the use of ICT as aspect of a discipline or profession; and finally, the use of ICT as medium for teaching and learning. Thus, information and communication technology has become an essential tool in students' academic development. This trend features the use of audio, visual, and animation effects in the English language teaching classrooms. ICT plays a positive role in improving activities and initiatives of students and teaching effect in the classrooms.

\subsection{Role of ICT in Language Teaching}

In the considerations of international education, ICT denotes a dominant strategy invested in the classrooms to improve the overall rate of education in almost all the fields of schooling. However, with regard to the context of foreign language education, the employment of ICTs has been, to an extent, one of the worthwhile procedure today's nations apply to guarantee the success of any 
language learning teaching enterprise. To begin with, the integration of ICTs in the language teaching-learning environments is becoming a primordial step since the consequences would be very fruitful. In this sense, Padurean and Margan (2009) state:

The application of ICT gives more opportunities for communication between peer learners: they can exchange information in real time, they can participate in blog discussions, work in teams on different projects, exchange emails, search for information, etc. By using the authentic material provided by the Internet, we will have a better insight into the culture of the country and people whose language we study. (p.98)

In this respect, language learners are supposed to be endowed with a variety of resourceful equipment which creates learning atmospheres that greatly assist the learnerse communication and awareness. Next, recent studies emphasize the fact that there is significant evidence that the use of ICT can have a number of benefits and advantages on language learners.

In support of this, Houcine (2011) estimates that the adoption of ICT results in many advantages. These can better be paraphrased in the following points:

a. ICT increases learners' motivation and consequently enhances learners' involvement.

b. ICT empowers independent learning.

c. ICT develops Learners ${ }^{\text {ee }}$ collaboration and communication while carrying out learning tasks.

d. Learners' attainment and outcomes are improved through the use of ICT.
Moreover, teaching the language through the implementation of ICT is not a fortune that only learners can benefit from; however, teachers of the language are, at the same time, taking advantages from theses educational tools. Above all, teachers using ICT can discover that their role is shifting from knowledge providers to facilitators of the learning process. In addition, and teachers are able to change and improve the teaching method since they make use of ICT. That is, they can bring their students into the world of networks where they can support their classroom teaching.

\subsection{Advantages of Using ICT in Language Teaching}

The use of ICT makes the learners more involved and increase the effectiveness of learning. So, there are many advantages of ICT in language teaching. First, ICT motivates students to achieve better and perform in a good way. Second, it also helps students to reflect on what and how they have learnt. It is seen as increasing learners' confidence and motivation by making school work more enjoyable. Simultaneously, it also enhances teachers' awareness about the positive impact of ICT, motivates students and improves their oral performance.

Subsequently, ICT enables learners to gather data that would be difficult or even impossible to obtain. And through ICT, teachers can easily explain complex instructions and ensure studentse comprehension. They are also able to create interactive classes and make the lessons more enjoyable, which could 
improve student attendance and concentration.

Anderson et al. (2005) states that ICT offers various advantages. One of them is to facilitate learning for children who have different learning styles and abilities, including slow learners, the socially disadvantaged, the mentally and physically handicapped, the talented, and those living in remote rural areas.

\section{METHOD}

This research tried to investigate the role of integrating Information and communication technology in teaching speaking; therefore, it conducted by using qualitative design. It is also useful to obtain an in-depth data and understand a particular phenomenon (Preissle, 2002). In addition, Cresswell (2008) defines a qualitative study as an inquiry process of understanding a social or human problem, based on building a complex, holistic picture, forms with words, reporting details views of informants, and conduct in natural setting.

This research conducted at English Study Program of FKIP UIR. The participants were students at the first semester of English Study Program FKIP UIR Pekanbaru.

The questionnaire aimed at collecting students' viewpoints about the use of ICTs in oral courses to develop their speaking abilities. The students' questionnaire was directed to first semester of English students (a population of 183 students) at English Study Program FKIP UIR. We have given the questionnaire to 42 students randomly selected to be a sample of the study.

\section{FINDING AND DISCUSSION}

\subsection{Data Description}

Based on data analysis technique, the researcher did several steps. First, the questionnaires were distributed to 42 students. This questionnaire is composed of 20 questions. It is divided into three sections. The first section is about background information ( 9 questions). From these questions, we collected the information about the students' gender, age, and technological devices and internet accessibility at home. The second section includes 7 questions which discusses about developing speaking skill. Then, the third section contains 4 questions. It is about students' opinions about the use of ICT in teaching speaking skill. The second step, data were collected; they were coded and classified based on the research questions. Each classification was analyzed and interpreted.

\subsubsection{Section one: Students' Background Information}

1. Questions no. 1: Gender

Table 1. Students' Gender

\begin{tabular}{ccc}
\hline Gender & $\begin{array}{l}\text { Number of } \\
\text { students }\end{array}$ & $\begin{array}{l}\text { Percentage } \\
(\%)\end{array}$ \\
\hline Male & 15 & $35,71 \%$ \\
Female & 27 & $64,29 \%$ \\
Total & 42 & $100 \%$ \\
\hline
\end{tabular}

The table shows that $64,29 \%$ of students are female while $35,71 \%$ are male. The purpose of this question is to know who prefers using ICT in teaching speaking skill. 
2. Question no. 2: Age

Table 2. Students' Age Distribution

\begin{tabular}{llll}
\hline Age & $\begin{array}{l}\mathbf{1 9} \\
\text { year }\end{array}$ & $\begin{array}{l}\mathbf{2 0} \\
\text { year }\end{array}$ & Total \\
\hline Number & 30 & 12 & 42 \\
$\begin{array}{l}\text { Percentage } \\
\text { \% }\end{array}$ & 71,43 & 28,57 & 100 \\
\hline
\end{tabular}

Based on table 2, we can shows that 30 students are 19 years old and about 28,57 \% are 20 years old. So, we concluded that no students above 20 .

3. Question no. 3: At home, do you have?

Table 3. Tools that Students have at home

\begin{tabular}{ccc}
\hline Choices & Students & $\begin{array}{c}\text { Percenta } \\
\text { ge (\%) }\end{array}$ \\
\hline Computer & 15 & $35.71 \%$ \\
Laptop & 35 & $83,33 \%$ \\
I Pad & 5 & $11,90 \%$ \\
Smartphone & 40 & $95,23 \%$ \\
\hline
\end{tabular}

In this question, the students choose more than one tools that they have at home. Therefore, the researcher calculated the percentage in each items based on the total number of students (42 students).

Based on the table 3, there were $95,23 \%$ of students have smartphone and $83,33 \%$ of them have a laptop. In contrast, only 5 students have I-pad and 15 students have computers. Finally, we can assume that most of students have to use high technology at home.

4. Question no. 4: Are you skillful enough to use these devices?

Table 4. Students' Ability in ICT use

Choices Students Percentage

(\%)

J-SHMIC, Vol 4, No 2, August 2017

\begin{tabular}{ccc}
\hline $\begin{array}{c}\text { Very } \\
\text { skillful }\end{array}$ & 20 & $47,62 \%$ \\
\hline Somehow & 18 & $42,86 \%$ \\
\hline Not at all & 4 & $9,52 \%$ \\
\hline Total & 42 & $100 \%$ \\
\hline
\end{tabular}

Researcher notice that 47,62 $\%$ of students were skillful enough to use these technologies. While $42,86 \%$ of students state that they did not skillful enough and $9,52 \%$ of them did not skillful in using these devices.

5. Question no. 5. Do you have internet access at home?

Table 5. Students' Access to Internet at home

\begin{tabular}{ccc}
\hline Choices & Students & Percentage (\%) \\
\hline Yes & 14 & $33,33 \%$ \\
No & 28 & $66,67 \%$ \\
Total & 42 & $100 \%$ \\
\hline
\end{tabular}

This question aims at knowing how many students have accessed to internet at home in order to see their skill in using it as well as using technological devices. So, based on the table 5 indicates that $66,67 \%$ of students did not have access to internet at home, while $33,33 \%$ of them state that they have it.

6. Question no. 6. Do you have any of the following accounts?

Table 6. Some Accounts that Students

Have

\begin{tabular}{ccc}
\hline Choices & Students & $\begin{array}{c}\text { Percentage } \\
(\boldsymbol{\%})\end{array}$ \\
\hline E-mail & 42 & $100 \%$ \\
Facebook & 42 & $100 \%$ \\
Twitter & 35 & $83,33 \%$ \\
You tube & 15 & $35,71 \%$ \\
\hline Instagram & 42 & $100 \%$ \\
\hline
\end{tabular}

The Roles of Integrating Information Communication Technology (ICT) in Teaching Speaking at the First Semester of English Students of FKIP UIR 
In this question, the students choose more than one accounts that they have. Therefore, the researcher calculated the percentage in each items based on the total number of students (42 students).

All of students or $100 \%$ of them said that they used e-mail, facebook, and instagram. Then, $83,33 \%$ of them said that they used twitter and only $35,71 \%$ of them have you-tube. In summary, most of students have more than one account and have used them.

7. Question no. 7. In addition to chatting, do you use these means for educational purposes?

Table 7. Students' Use of Technology for Educational Purposes

\begin{tabular}{ccc}
\hline Choices & Students & Percentage (\%) \\
\hline Yes & 34 & $80,95 \%$ \\
No & 8 & $19,05 \%$ \\
Total & 42 & $100 \%$ \\
\hline
\end{tabular}

Table 7 notices that $80,95 \%$ of students from the whole sample used technology for educational purposes. While $19,05 \%$ of them or 8 students did not use it for studying.

8. Question no. 8. Do you use technological tools (ICT) in speaking class?

Table 8. Students Use of ICT in Speaking class

\begin{tabular}{ccc}
\hline Choices & Students & $\begin{array}{c}\text { Percentage } \\
(\boldsymbol{\%})\end{array}$ \\
\hline Yes & $\mathbf{4 2}$ & $\mathbf{1 0 0 \%}$ \\
No & $\mathbf{0}$ & $\mathbf{0 \%}$ \\
Total & $\mathbf{4 2}$ & $\mathbf{1 0 0 \%}$ \\
\hline
\end{tabular}

All students said that they used Information Communication Technology tools in their speaking class. This indicates that they work with Wi-Fi at campus to access internet by using laptop, notebook and mobile phone.

9. Question no 9. How often do you use them (ICT)?

Table 9. The Frequency of Using ICT

\begin{tabular}{ccc}
\hline Choices & Students & $\begin{array}{c}\text { Percentage } \\
(\mathbf{\%})\end{array}$ \\
\hline Always & 5 & $11,90 \%$ \\
Often & 25 & $59,53 \%$ \\
Sometimes & 10 & $23,81 \%$ \\
Rarely & 2 & $4,76 \%$ \\
Total & 42 & $100 \%$ \\
\hline
\end{tabular}

The table reveal that $59,53 \%$ of students used ICT devices, while $23,81 \%$ of them used devices, and $11,90 \%$ used the devices. Only 2 students $(4,76 \%)$ rarely used ICT.

\subsubsection{Section two: Developing Students Speaking Skill}

10. Question no 10. Is Speaking English for you

Table 10. Speaking in English

\begin{tabular}{ccc}
\hline Choices & Students & $\begin{array}{c}\text { Percentage } \\
(\%)\end{array}$ \\
\hline Easy & 26 & $61,90 \%$ \\
Very easy & 0 & $0 \%$ \\
Difficult & 16 & $38,10 \%$ \\
$\begin{array}{c}\text { Very } \\
\text { difficult }\end{array}$ & 0 & $0 \%$ \\
total & 42 & $100 \%$ \\
\hline
\end{tabular}

This table demonstrated that the majority of students find that speaking was easy $(61,90 \%)$, and $38,10 \%$ of them said that English was difficult. While no students said that English was very easy or very difficult. 
11. Question no 11. Do you speak English outside the classroom?

Table 11. Using English Outside Classroom

\begin{tabular}{ccc}
\hline Choices & Students & $\begin{array}{c}\text { Percentage } \\
(\mathbf{\%})\end{array}$ \\
\hline Yes & 24 & $57,14 \%$ \\
No & 18 & $42,86 \%$ \\
Total & 42 & $100 \%$ \\
\hline
\end{tabular}

From table 11, we can show that more than half students (24 students) used English outside the classroom, while $42,86 \%$ did not use because of lack of vocabulary and afraid of making mistakes while speaking.

12. Question no 12. Do you listen to English records outside the classroom?

If yes, which type do you prefer?

Table 12. Students listen to English Records

\begin{tabular}{ccc}
\hline Choices & Students & $\begin{array}{c}\text { Percentage } \\
(\boldsymbol{\%})\end{array}$ \\
\hline Films & 37 & $88,09 \%$ \\
\hline $\begin{array}{c}\text { Songs } \\
\text { Audio } \\
\text { books }\end{array}$ & 42 & $100 \%$ \\
other & 0 & $0 \%$ \\
\hline
\end{tabular}

The table showed that whole students (100\%) were listened to English records outside the classroom, at home or elsewhere. All students enjoyed listening to songs, while 37 students loved listening to films. Only $11,90 \%$ of them enjoyed listening other liked you-tube, news, and video. Then, no students liked listening to audio books.

13. Question no. 13. How much do you enjoy the speaking class?
Table 13. Students' Preferences

\begin{tabular}{ccc}
\hline Choices & Students & $\begin{array}{c}\text { Percentage } \\
(\%)\end{array}$ \\
\hline Very much & 30 & $71,43 \%$ \\
Somehow & 8 & $28,57 \%$ \\
Not at all & 0 & $0 \%$ \\
Total & 42 & $100 \%$ \\
\hline
\end{tabular}

This question was asked in order to identify if students enjoyed the speaking class or not. We found that $71,43 \%$ of students enjoyed whereas $28,57 \%$ of them did not.

14. Question no. 14. Does the method used by your speaking lecturer to develop your speaking ability satisfy your needs?

Table 14. Method used by Lecturer of Speaking

\begin{tabular}{ccc}
\hline Choices & Students & $\begin{array}{c}\text { Percentage } \\
(\boldsymbol{\%})\end{array}$ \\
\hline Yes & 35 & $83,33 \%$ \\
No & 7 & $16,67 \%$ \\
Total & 42 & $100 \%$ \\
\hline
\end{tabular}

The table showed that most of students $(83,33 \%)$ found that the method used by their lecturer was suitable and helpful to develop their speaking skill; however, $16,67 \%$ of them said that it did not effective in improving their speaking abilities. If 'no', say if it is because of:

\begin{tabular}{lcc}
\hline \multicolumn{1}{c}{ Choices } & Students & $\begin{array}{c}\text { Percentage } \\
(\%)\end{array}$ \\
\hline $\begin{array}{l}\text { The types of } \\
\text { teaching } \\
\text { materials } \\
\begin{array}{l}\text { The type of } \\
\text { activities }\end{array}\end{array}$ & 2 & $28,57 \%$ \\
$\begin{array}{l}\text { The degree } \\
\text { of teacher's } \\
\text { interaction } \\
\text { No variation } \\
\text { of technique }\end{array}$ & 3 & $42,86 \%$ \\
Total & 2 & $28,57 \%$ \\
\hline
\end{tabular}


This question was related to the previous one. The idea behind this question was to know the difficulties and the problems that student in relation to the method used by their lecturer.

Based on the table, $42,86 \%$ of students thought that the method used by their lecturer did not satisfy their needs because of the degree of lecturer interaction. While $28,57 \%$ of them said that it was because of type of teaching materials and no variation of techniques.

15. Question no 15. Which of the following techniques do you prefer?

Table 15. Techniques that Students' Prefer

\begin{tabular}{lcc}
\hline \multicolumn{1}{c}{ Choices } & Students & $\begin{array}{c}\text { Percentage } \\
(\%)\end{array}$ \\
\hline $\begin{array}{l}\text { Information } \\
\text { Gap }\end{array}$ & 0 & $0 \%$ \\
Activities & & \\
Students' & 25 & $59,52 \%$ \\
Presentation & & $95,23 \%$ \\
Discussion & 40 & $88,09 \%$ \\
Role Play & 37 & $47,62 \%$ \\
Group Work & 20 & \\
\hline
\end{tabular}

In this question, the students choose more than one techniques that they have prefered. Therefore, the researcher calculated the percentage in each items based on the total number of students (42 students).

As shown in table $95,23 \%$ of students prefered to use discussion, $88,09 \%$ of them liked to use role play, $59,52 \%$ liked to prefer students' presentation. While, there was no students prefered to use information gap activities. Therefore, students have different preferences concerning the techniques used to develop their speaking skill. This was directly related to their learning style and strategies.

16. Question no 16. Does your lecturer of speaking use ICT in the classroom?

Table 16. Lecturer's Use of ICT in the

\begin{tabular}{ccc} 
Choices & Students & $\begin{array}{c}\text { Percentages } \\
(\%)\end{array}$ \\
\hline Yes & 42 & $100 \%$ \\
No & 0 & $0 \%$ \\
Total & 42 & $100 \%$ \\
\hline
\end{tabular}

We asked students in order to know whether lecturer used ICT while teaching speaking. Based on the table, showed that all of students $(100 \%)$ said that their lecturers used technology (ICT) in the classroom.

\subsubsection{Section three: The Importance of Information Communication Technology (ICT) in Speaking Class.}

17. Question no 17. Do you find the use of information communication technology (ICT) in teaching English beneficial for you?

Table 17. The Use of ICT in the Classroom

\begin{tabular}{ccc}
\hline \multicolumn{2}{c}{ Table 17. The Use of ICT in the Classroom } \\
\hline Choices & Students & $\begin{array}{c}\text { Percentage } \\
(\%)\end{array}$ \\
\hline Yes & 40 & $95,24 \%$ \\
No & 2 & $4,76 \%$ \\
total & 42 & \\
\hline
\end{tabular}

Based on the table, nearly 95\% reports that they feel that the used of ICTs was really helpful for them while $4,76 \%$ said the opposite.

18. Question no 18. Does the use of ICT in Speaking class increase your? 
Table 18. Advantages of ICTs in Speaking Class

\begin{tabular}{ccc}
\hline Choices & Students & $\begin{array}{c}\text { Percentage } \\
(\mathbf{\%})\end{array}$ \\
\hline Knowledge & 42 & $100 \%$ \\
\hline Motivation & 32 & $76,19 \%$ \\
Creativity & 15 & $35,71 \%$ \\
\hline
\end{tabular}

In this question, the students choose more than one techniques that they have prefered. Therefore, the researcher calculated the percentage in each items based on the total number of students (42 students).

We can show that $100 \%$ of students think that the aspect was affected by technology were knowledge, then motivation $(76,19 \%)$. While 15 of students $(35,71 \%)$ said that it was affected their creativity.

19. Does the use of ICT develop your speaking skill?

Table 19. The Use of ICT in Developing Students' Speaking Skill

\begin{tabular}{ccc}
\hline Choices & Students & $\begin{array}{c}\text { Percentage } \\
(\boldsymbol{\%})\end{array}$ \\
\hline Yes & 42 & $100 \%$ \\
No & 0 & $0 \%$ \\
Total & 42 & $100 \%$ \\
\hline
\end{tabular}

Through this question, we wanted to discover if the used of technology develops students' speaking skill. The results showed that all of students agreed that technology have developed their speaking skill.

20. Which kind of technology do you prefer your lecturer to use in teaching speaking?
Table 20. Students' Preferences in the Kind of Technology (ICT)

\begin{tabular}{ccc}
\hline Choices & Students & $\begin{array}{c}\text { Percentage } \\
(\boldsymbol{\%})\end{array}$ \\
\hline Video & 36 & $85,71 \%$ \\
Computer & 10 & $23,80 \%$ \\
Laptop/ & 40 & $95,23 \%$ \\
Notebook & & \\
Projector & 38 & $90,47 \%$ \\
\hline
\end{tabular}

This question was addressed to the students for purpose of knowing their opinion about their preferences kind of technology that can be used in teaching speaking. From the students' answered, 95,23\% prefered their lecturer to use laptop/notebook and $90,47 \%$ of them prefered their lecturer to use projector. While $85,71 \%$ prefered their lecturer to use video, then only $23,80 \%$ of them prefered their lecturer to use computer.

\section{CONCLUSION}

From the students' questionnaire results, it has been revealed that most of the students possess a technological device being a computer, laptop, Ipad or a smart phone not only for chatting but also for educational purposes as well. Most students confessed to be skillful enough to use these devices. Besides, the some of them have internet accessed at home. Furthermore, some students have found that speaking in English was difficult, while the majority of them find it an easy task. Some other students, however, saw the method used by their teacher did not effective in ameliorating their speaking abilities because of problems like the degree of teacher's interaction. In general, students prefer group work activities, free discussion, role play, or students' presentation. A 
large number of students declared that their lecturer use technology while teaching speaking. They claimed that using high technologies is beneficial and helpful to speak the language. Finally, most students affirmed that the used of ICTs developed their speaking skill and increased their knowledge, creativity and motivation. Concerning their attitudes towards their preferable kind of technology that can be used in teaching, some prefer to use laptop/notebook and projector while others enjoy watching videos.

\section{REFERENCES}

Anderson, J., Semenov, A., Pereverzev, L. and BulinSokolova, E. (2005). Information and communication technologies in schools. Paris: Unesco.

Al-Zaidiyeen, N. J. (2010). Teachers ${ }^{\text {ee }}$ Attitudes and Levels of Technology Use in Classrooms, International Education Studies, 3 (2), 211-218.

Ashaver, D., Igyuve, S. M. (2013). The Use of Audio-Visual Materials in the Teaching and Learning Processes in Colleges of Education in Benne State. Negeria, IOSR Journal of Research and Method in Education, 1 (6), 44-55.

Egan, K. B. (1999). Speaking: A Critical Skill and a Challenge, CALICO Journal, 16 (3), 227293.

Harmer, J. (2008). The Practice of English Language Teaching.
Harlow, England: Pearson Longman.

Madhavaiah, G., Nagaraju, Ch., Peter,S. (2013). Importance of Technology in Teaching and Learning English Language, International Journal of Scientific Research and Reviews. 2 (3), 146-154

Maggioli, G. D. (2009). Teaching English with Technology. Pearson: Longman.

Owen-Jackson, G. (2000). Learning to Teach Design and Technology in the Secondary School. London: Routledge Falmer.

Padurean, A., \& Margan, M. (2009). Foreign Language Teaching Via ICT. Revista De Informatică Socială, 6 (12), 97-101.

Pun, M. (2013). The Use of Multimedia Technology in English language Teaching, International Journal of Interdisciplinary Studies, 1 (1), 29-30.

Shyamlee, S. D., Phil, M. (2012). Use of Technology in English language Teaching and Learning, IACSIT press, vol. 33, 150-156.

Sorensen, E. and Ó Murchú, D. (2006). Enhancing learning Through Technology. Hershey, PA: Information Science Pub.

Ur, P. (1996). A Course in Language Teaching: Practice and Theory. Cambridge University Press. 